\title{
RESPONSE FROM ANAEROBIC DIGESTION OF LAYING HEN MANURE WITH BIOCHAR ADDITION
}

\author{
Willian R. Andrade ${ }^{*}$, Cecilia de F. S. Ferreira², Richard S. Gates ${ }^{3}$, Alisson C. Borges², \\ Tânia M. B. dos Santos ${ }^{4}$
}

${ }^{1 *}$ Corresponding author. Faculdade de Medicina Veterinária e Zootecnia, Universidade de São Paulo/ Pirassununga - SP, Brasil.
E-mail: willianrufino@usp.br| ORCID: https://orcid.org/0000-0002-3030-780X

\section{KEYWORDS}

biogas yield, total ammonia nitrogen, volatile solids.

\begin{abstract}
This study aimed to assess the anaerobic digestion response of laying hen manure with different inclusion levels of biochar in batch reactors as measured by physicochemical parameters, biogas production and digestate quality. Four levels of biochar inclusions $(0$, 2.5, 5.0 and $7.5 \%$ ) were tested with 3 replicates each. Twelve two-liter anaerobic batch reactors were used for 86 days at $35^{\circ} \mathrm{C}$. Substrate and digestate of each treatment were assessed for monitored parameters, biogas production and digestate quality. Increased levels $(0,2.5,5.0$ and $7.5 \%)$ of biochar were found to gradually reduce total ammonia nitrogen $\left(1794.33,140.84,950.81\right.$ and $509.32 \mathrm{mg} . \mathrm{L}^{-1}$, respectively). Despite the positive effect of biochar to accelerate initial biogas production, its use at any inclusion rate did not contribute significantly to biogas production in terms of biogas yield or digestate quality as compared to control treatment.
\end{abstract}

\section{INTRODUCTION}

Anaerobic digestion (AD) has been well studied and used as a tool for harnessing valuable sub-products, however, it still has some incovenient problems in terms of reactor monitoring parameters that may strongly affect biogas production (Dalkilic \& Ugurlu, 2015; Cuetos et al., 2017; Wang et al., 2019). High levels of total ammoniacal nitrogen (TAN) which suppress anaerobic microbes have been cited as one of the main issues regarding anaerobic digestion of laying hen manure (Massé \& Singh, 2013; Farrow et al., 2016; Molaey et al., 2018).

Rich protein biomass used as a substrate in anaerobic reactors may lead to a severe disturbance from resulting high ammonia concentration, causing reduced activity of microorganisms and incomplete digestion of intermediate products such as volatile fatty acids, thereby decreasing methanogenic activity (Jian et al., 2019). Increased TAN above a certain threshold may strongly affect $A D$ performance; Dalkilic \& Ugurlu (2015) reported that TAN concentrations up to $3000 \mathrm{mg} . \mathrm{L}^{-1}$ decreased biogas production while Wang et al. (2019) encountered that TAN concentration above $1600 \mathrm{mg} . \mathrm{L}^{-1}$ can strongly affect the AD system's efficiency specifically in terms of solids removal efficiency. These authors also recommended that the ideal TAN concentration for AD of poultry manure should be around $800 \mathrm{mg} . \mathrm{L}^{-1}$.

Alternatives to overcome negative effects of high TAN concentration during anaerobic digestion have been studied. These include anaerobic co-digestion (Wang et al., 2014; Zhang et al., 2014), acclimation of microorganism (Yenigün \& Demirel, 2013), dilution (Yun et al., 2016), and use of adsorbent substances (Cuetos et al., 2017). However, very few studies have focused on the use of adsorbent material aiming to improve the energetic performance and monitoring parameters of poultry manure AD.

Biochar is an adsorbent material, generated by pyrolysis of biomass conducted under high temperature in the absence of oxygen (Guo et al., 2016). Its use as a component in $\mathrm{AD}$ is relatively new but some studies that have been carried out with biochar noted its positive impact by allowing better stability and overall equilibrium of fermentative reactions (Ho \& Ho, 2012; Luo et al., 2015; Cuetos et al., 2017 and Pan et al., 2019). Biochar's pore structure coupled with its electrical conductivity may provide a higher potential for volatile fraction degradation by concentrating and immobilizing microorganisms on the organic fraction (Luo et al., 2015).

\footnotetext{
${ }^{2}$ Departamento de Engenharia Agrícola, Universidade Federal de Viçosa/ Viçosa - MG, Brasil.

${ }^{3}$ Egg Industry Center, Iowa State University/ Ames, USA.

${ }^{4}$ Universidade Estadual de Mato Grosso do Sul/ Aquidauana - MS, Brasil.
} 
The adsorption phenomena of biochar with other substrates may improve digestion by: a) sorption of inhibitory components through its pores and sites for binding, b) increase buffering capacity, and c) formation of a biofilm to immobilize microorganism (Mumme et al., 2014; Luo et al., 2015 and Pan et al., 2019).

The present study proposed to assess the $\mathrm{AD}$ response of laying hen manure with different inclusion rate of biochar in batch anaerobic reactors with respect to physicochemical parameters and biogas production yield.

\section{MATERIAL AND METHODS}

The study was conducted in the Anaerobic Digestion Laboratory in the Department of Agricultural Engineering at the Federal University of Viçosa (UFV). To perform the study, twelve anaerobic batch reactors of $2 \mathrm{~L}$ each were kept under controlled temperature at $35^{\circ} \mathrm{C}$. Three levels $(2.5 ; 5.0$ and $7.5 \%$ by mass) of biochar inclusion plus the control were utilized, with each treatment replicated three times. A completely randomized design formed by 4 treatments and 3 replications was adopted.

Manure used in the experiment was collected from beneath cages in the laying hen barns of the Animal Science Department at Federal University of Viçosa. At the time of collection, manure was homogenized, and it was composed primarily of excreted feces, plus some feed waste, cracked eggs, insects, larva and particulate matter. The homogenized mixture was placed in plastic bags and transported to the Anaerobic Digestion Laboratory in the Agricultural Engineering Department. The biochar was made of pyrolyzed broiler chicken litter provided by a company from Sao Paulo State (SP Pesquisa e Tecnologia Ltda.).

To perform the physicochemical characterization of manure, biochar, substrates, and digestates, the following measurement were made: $\mathrm{pH}$, total ammonia nitrogen
(TAN), total solids (TS), and volatile solids (VS) according to the methodologies suggested by APHA, AWWA, WPCF (2017). Total carbon (TC) was determined by a gravimetric method which consisted of placing samples in a furnace for combustion at $550^{\circ} \mathrm{C}$ for four hours. After that, the residual total organic matter (TOM) was weighed and computed as percentage of initial dry matter. TC was obtained from a conversion factor (1.8:1 OM:TC) as suggested by Jiménez \& Garcia (1992). Determination of total nitrogen (TN), phosphorous (P), and calcium (Ca) followed methodologies suggested by APHA, AWWA, WPCF, (2017). Table 1 lists the mean values of the parameters that characterize the laying hen manure and biochar.

TABLE 1. Mean values of characterization parameters from laying hen manure and biochar made of broiler litter.

\begin{tabular}{lll}
\hline \multicolumn{1}{c}{ Parameters } & Manure & Biochar \\
\hline $\mathrm{pH}$ & 9.47 & 10.29 \\
Total ammonia nitrogen $\left(\mathrm{mg} . \mathrm{L}^{-1}\right)$ & 997.50 & 52.50 \\
Total Solids (\%) & 55.71 & 62.98 \\
Volatile solids (\% of DM) & 70.38 & 53.40 \\
T- Carbon (\% of DM) & 30.95 & 29.66 \\
T-Nitrogen (\% of DM) & 2.83 & 2.17 \\
T-Phosphorous (\% of DM) & 4.76 & 3.12 \\
Calcium (\% of DM) & 2.71 & 0.81 \\
\hline
\end{tabular}

For AD, twelve two-liters batch anaerobic reactors were used (figure 1). Each reactor had a hose barb on top connected to flexible tubing for gas to move to the gas collector, which consisted of two concentric cylindrical PVC pipes, with the outer pipe containing water to trap the collected gas.

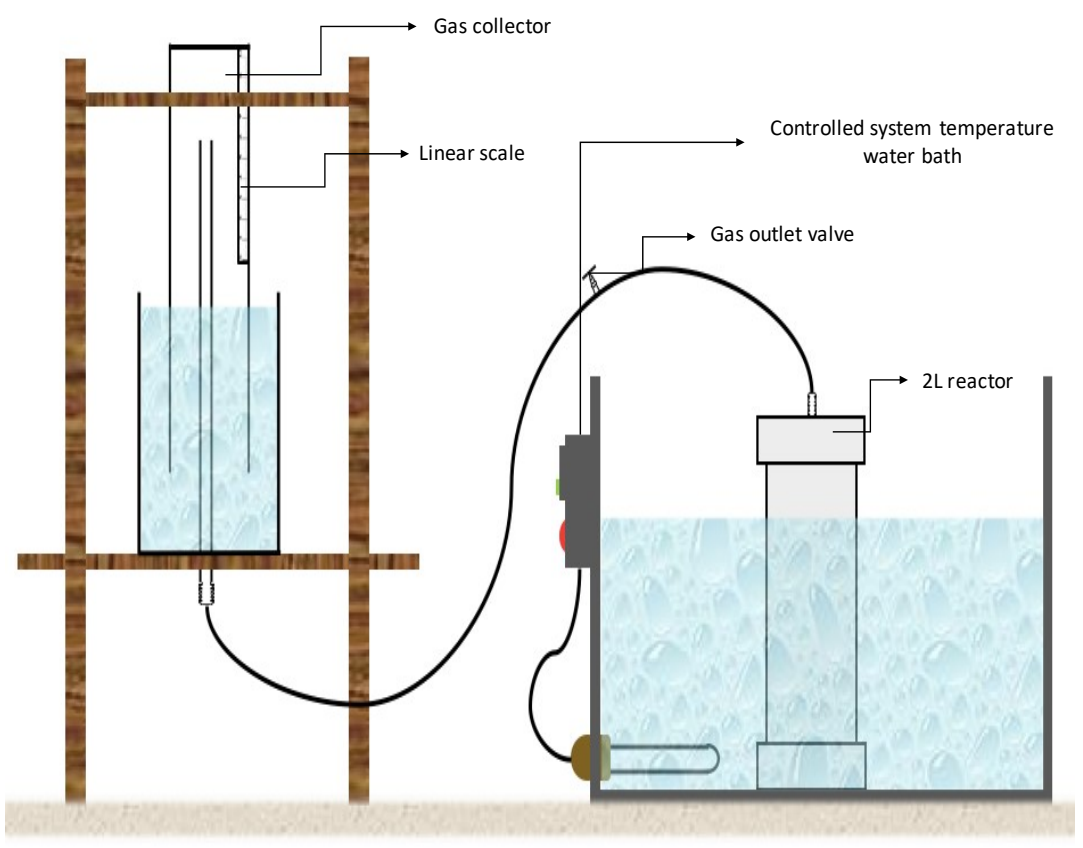

FIGURE 1. Schematic representation of an anaerobic reactor used in the experiment.

All substrates to feed reactors were adjusted with deionized water to attain $7 \%$ of total solids (TS) of the manure and biochar mixtures. Formulated material used to feed reactors expressed in mass percent are displayed in table 2. 
TABLE 2. Amount (\% by mass) of each component used to feed batch anaerobic reactors represented as percent (\%) of the total substrate $(\mathrm{kg})$ and their respective amount of total and volatile solids (on dry matter basis).

\begin{tabular}{ccccccc}
\hline Treatment & Manure & Water & Biochar & Total $(\mathrm{kg})$ & TS $(\%)$ & VS $(\%)$ \\
\hline Control & 15.16 & 84.84 & 0 & 2.5 & $7.0 \pm 0.21$ & 65.16 \\
$2.5 \%$ of biochar & 13.24 & 85.08 & 1.68 & 2.5 & $7.0 \pm 0.04$ & 65.46 \\
$5.0 \%$ of biochar & 11.36 & 85.24 & 3.36 & 2.5 & $7.0 \pm 0.09$ & 66.09 \\
$7.5 \%$ of biochar & 9.48 & 85.48 & 5.04 & 2.5 & $7.0 \pm 0.27$ & 61.09 \\
\hline
\end{tabular}

All twelve anaerobic reactors were simultaneously sealed, placed inside a bath half-filled with water and kept there under controlled temperature at $35^{\circ} \mathrm{C}$ throughout the entire experiment. The batch time was 86 days and biogas production was recorded daily.

To measure the volume of generated biogas, a linear scale was attached to the gas collector (as seen in the figure 1) to record its displacement as pressure mounted by the generated gas. The value was multiplied by the inner crosssectional area of the collector, assumed to be at local standard atmospheric pressure of $95.05 \mathrm{kPa}$. Biogas volume was corrected to $1 \mathrm{~atm}$ and $20^{\circ} \mathrm{C}$ using an equation resulting from the combination of Boyle's and Gay-Lussac's law. Biogas yield was calculated using data from daily biogas production and expressed in $\mathrm{m}^{3}$ of biogas per $\mathrm{kg}$ of TS and $\mathrm{VS}_{\text {in }}$ and $\mathrm{VS}_{\text {removed. }}$
The experiment was a completely randomized design in with four treatments replicated three times each. The data were analyzed by a one-way ANOVA (analysis of variance) using Speed Stat software (Carvalho \& Mendes, 2017). Mean values of all treatments were separated using a Tukey test with $5 \%$ level of significance.

\section{RESULTS AND DISCUSSION}

Treatment means of $\mathrm{pH}$ and total ammonia nitrogen (TAN) of substrates and digestate are presented in table 3. Mean substrate $\mathrm{pH}$ used to feed the reactors were different from one another $(\mathrm{P}<0.05)$ while $\mathrm{pH}$ digestate values were not affected by inclusions of biochar (Table 3). Total ammonia nitrogen (TAN) increased at the end of the experiment by about 3.2 times as compared to the initial. Higher inclusions of biochar (at 7.5\%) led to lower TAN concentration in both substrate and digestate.

TABLE 3. Mean values for $\mathrm{pH}$, total ammonia nitrogen (TAN mg. $\mathrm{L}^{-1}$ ), TS and VS reduction (\%) and C: $\mathrm{N}$ ratio of substrate and digestate from batch anaerobic reactors fed laying hen manure different levels of biochar.

\begin{tabular}{ccclllll}
\hline \multirow{2}{*}{ Parameters } & \multicolumn{2}{c}{ Control } & $\begin{array}{l}\text { Biochar } \\
2.5 \%\end{array}$ & $\begin{array}{l}\text { Biochar } \\
5.0 \%\end{array}$ & Biochar 7.5\% & P value & CV (\%) \\
\hline \multirow{2}{*}{$\mathrm{pH}$} & Substrate & $8.87 \mathrm{~d}$ & $9.17 \mathrm{c}$ & $9.37 \mathrm{~b}$ & $9.73 \mathrm{a}$ & 0.001 & 0.38 \\
\multirow{2}{*}{ TAN } & Digestate & $8.32 \mathrm{a}$ & $8.44 \mathrm{a}$ & $8.48 \mathrm{a}$ & $8.53 \mathrm{a}$ & 0.105 & 1.08 \\
& Substrate & $547.75 \mathrm{a}$ & $568.33 \mathrm{a}$ & $469.00 \mathrm{ab}$ & $324.33 \mathrm{~b}$ & 0.006 & 14.64 \\
& Digestate & $1794.33 \mathrm{a}$ & $1401.84 \mathrm{~b}$ & $950.81 \mathrm{c}$ & $509.32 \mathrm{~d}$ & 0.001 & 6.87 \\
\hline \multicolumn{2}{c}{ TS reduction (\%) } & $32.88 \mathrm{~b}$ & $43.86 \mathrm{a}$ & $38.77 \mathrm{ab}$ & $45.20 \mathrm{a}$ & 0.002 & 6.61 \\
\multicolumn{2}{c}{ VS reduction (\%) } & $55.50 \mathrm{a}$ & $57.40 \mathrm{a}$ & $54.07 \mathrm{a}$ & $55.02 \mathrm{a}$ & 0.576 & 5.20 \\
\hline \multirow{2}{*}{$\mathrm{C}: \mathrm{N}$ ratio } & Substrate & $12.20 \mathrm{~b}$ & $15.70 \mathrm{a}$ & $15.53 \mathrm{a}$ & $14.70 \mathrm{a}$ & 0.001 & 5.01 \\
& Digestate & $5.29 \mathrm{a}$ & $5.62 \mathrm{a}$ & $6.07 \mathrm{a}$ & $5.68 \mathrm{a}$ & 0.231 & 7.30 \\
\hline
\end{tabular}

Means followed by different letters in the same row differ at $5 \%$ through Tukey test.

Both substrate and digestate $\mathrm{pH}$ values after 86 days of $\mathrm{AD}$ were within the acceptable range of 6.0 to 8.0 (Andrade et al., 2016) recommended for AD, but there was a decrease of values from the beginning to the end which is an indicative of system's attempt to achieve stability.

Treatments that had only laying hen manure contributed to greater increase of TAN concentration, but it was still below the AD limit (3000 to $4000 \mathrm{mg} . \mathrm{L}^{-1}$, Niu et al. 2014). As observed by Cuetos et al., (2017), addition of larger amounts of activated carbon tend to minimize inhibitory occurrence in anaerobic reactors fed high nitrogen content biomass since total nitrogen is lower compared to treatments with lower inclusions of activated carbon. In the present study, inclusion of biochar resulted in a lower increase in TAN concentrations for both substrate and digestate, presumably from a lower load of rich organic matter which elicited less generation of TAN.
Biochar inclusion affected TS reduction (Table 3), while no effect was noted for VS reduction. In terms of TS, the $7.5 \%$ biochar treatment was higher than the control treatment and similar to the 2.5 and $5.0 \%$ treatments. The volatile fraction reduction averaged $55.5 \%$, quite similar to the $56.6 \%$ achieved by Rahman et al. (2018) working with poultry droppings under mesophilic condition, and 59.8\% achieved by Farias et al. (2012) with anaerobic batch reactors fed old laying hen manure with TS load of about $4 \%$. Usually, lower amounts of TS are recommended for feeding anaerobic reactors to mitigate toxic effects of TAN.

Substrate C:N ratio was higher in all treatments compared to the control treatment with values ranging from 14.70 to $15.70 \%$ (Table 3) vs $12.2 \%$. No statistical difference was observed for $\mathrm{C}: \mathrm{N}$ ratio for digestate with values ranging from 5.29 to 6.07 . Substrates of treatments 
with biochar inclusion had better $\mathrm{C}: \mathrm{N}$ ratio with values in the range recommended by Niu et al. (2014) of 13:1 to 28:1. All C:N ratios for digestate samples were low compared to optimum values for the AD process, however, the lower values are indicative that digestate was already stabilized.
Higher biogas yield per kilogram feedstock, substrate, TS in, VS in and VS removed $\left(\mathrm{m}^{3} \cdot \mathrm{kg}^{-1}\right)$ were attained by the control (Table 4). Inclusions of $2.5 \%$ biochar displayed better performance in terms of biogas yield as compared to the other inclusions, despite being significantly lower than the control.

TABLE 4. Mean values for biogas yield per kilogram of waste $\left(\mathrm{m}^{3} \cdot \mathrm{kg}^{-1}\right)$, biogas yield per kilogram of substrate $\left(\mathrm{m}^{3} \cdot \mathrm{kg}^{-1}\right)$, biogas yield per kilogram of TS in $\left(\mathrm{m}^{3} \cdot \mathrm{kg}^{-1}\right)$, biogas yield per kilogram of VS in $\left(\mathrm{m}^{3} \cdot \mathrm{kg}^{-1}\right)$ and biogas yield per kilogram of VS removed $\left(\mathrm{m}^{3} \cdot \mathrm{kg}^{-1}\right)$ of substrate and digestate from anaerobic batch reactors fed laying hen manure with different inclusions of biochar.

\begin{tabular}{|c|c|c|c|c|c|c|}
\hline Parameters & Control & $\begin{array}{l}\text { Biochar } \\
2.5 \%\end{array}$ & $\begin{array}{l}\text { Biochar } \\
5.0 \%\end{array}$ & $\begin{array}{l}\text { Biochar } \\
7.5 \%\end{array}$ & $\mathrm{P}$ value & $\mathrm{CV}(\%)$ \\
\hline Biogas yield per $\mathrm{kg}$ of waste $\left(\mathrm{m}^{3} \cdot \mathrm{kg}^{-1}\right)$ & $0.025 \mathrm{a}$ & $0.015 \mathrm{~b}$ & $0.009 \mathrm{c}$ & $0.006 \mathrm{c}$ & 0.001 & 13.42 \\
\hline Biogas yield per $\mathrm{kg}$ of substrate $\left(\mathrm{m}^{3} \cdot \mathrm{kg}^{-1}\right)$ & $0.007 \mathrm{a}$ & $0.004 \mathrm{~b}$ & $0.002 \mathrm{c}$ & $0.002 \mathrm{c}$ & 0.001 & 13.85 \\
\hline Biogas yield per $\mathrm{kg}$ of $\mathrm{TS}$ in $\left(\mathrm{m}^{3} \cdot \mathrm{kg}^{-1}\right)$ & $0.134 \mathrm{a}$ & $0.064 \mathrm{~b}$ & $0.035 \mathrm{c}$ & $0.022 \mathrm{c}$ & 0.001 & 13.58 \\
\hline Biogas yield per $\mathrm{kg}$ of $\mathrm{VS}$ in $\left(\mathrm{m}^{3} \cdot \mathrm{kg}^{-1}\right)$ & $0.203 \mathrm{a}$ & $0.101 \mathrm{~b}$ & $0.052 \mathrm{c}$ & $0.035 \mathrm{c}$ & 0.001 & 14.16 \\
\hline Biogas yield per $\mathrm{kg}$ of $\mathrm{VS}$ re $\left(\mathrm{m}^{3} \cdot \mathrm{kg}^{-1}\right)$ & $0.366 \mathrm{a}$ & $0.177 \mathrm{~b}$ & $0.096 \mathrm{c}$ & $0.064 \mathrm{c}$ & 0.001 & 16.33 \\
\hline
\end{tabular}

Means followed by different letters in the same row differ at $5 \%$ through Tukey test.

It was clearly noticed that as biochar inclusion increased biogas production decreased, and that effect might be due to the proportions of each component used to feed the reactors. In terms of biogas yield per kilogram of $\mathrm{VS}_{\text {in, }}$ the achieved values (Table 4) were quite similar to other research with similar experimental conditions found in the literature by: Farias et al. (2012) of $0.21 \mathrm{~m}^{3} \cdot \mathrm{kg}^{-1} \mathrm{VS}$ in and Fantozzi \& Buratti (2009) of $0.22 \mathrm{~m}^{3} \cdot \mathrm{kg}^{-1} \mathrm{VS}$ in, but lower than Zanato (2014) of $0.39 \mathrm{~m}^{3} \cdot \mathrm{kg}^{-1} \mathrm{VS}_{\text {in. Our findings }}$ were higher than that found by Vicente Jr et al. (2018) of $0.166 \mathrm{~m}^{3} \cdot \mathrm{kg}^{-1} \mathrm{VS}$ in even though they used poultry feces as substrate in the AD process. High $\mathrm{pH}$ of all digestate and improper $\mathrm{C}: \mathrm{N}$ ratio may have led to kinetic instabilities, affecting biogas yield.

All inclusions of biochar reduced biogas yield per kilogram of TS and VS in $\left(\mathrm{m}^{3} \cdot \mathrm{kg}^{-1}\right)$. The extent of decrease in biogas yield per kilogram of VS removed as compared to control treatment were 51,74 and $83 \%$, for $2.5 ; 5.0$ and $7.5 \%$ of biochar inclusions, respectively.

As see in figure 2, biogas production in treatments peaked in the first days and it was not as prominent as expected, and that probably happened due to the high $\mathrm{pH}$ of all substrates used to feed the reactors. By contrast, the control biogas production was toward the latter half of the experiment.

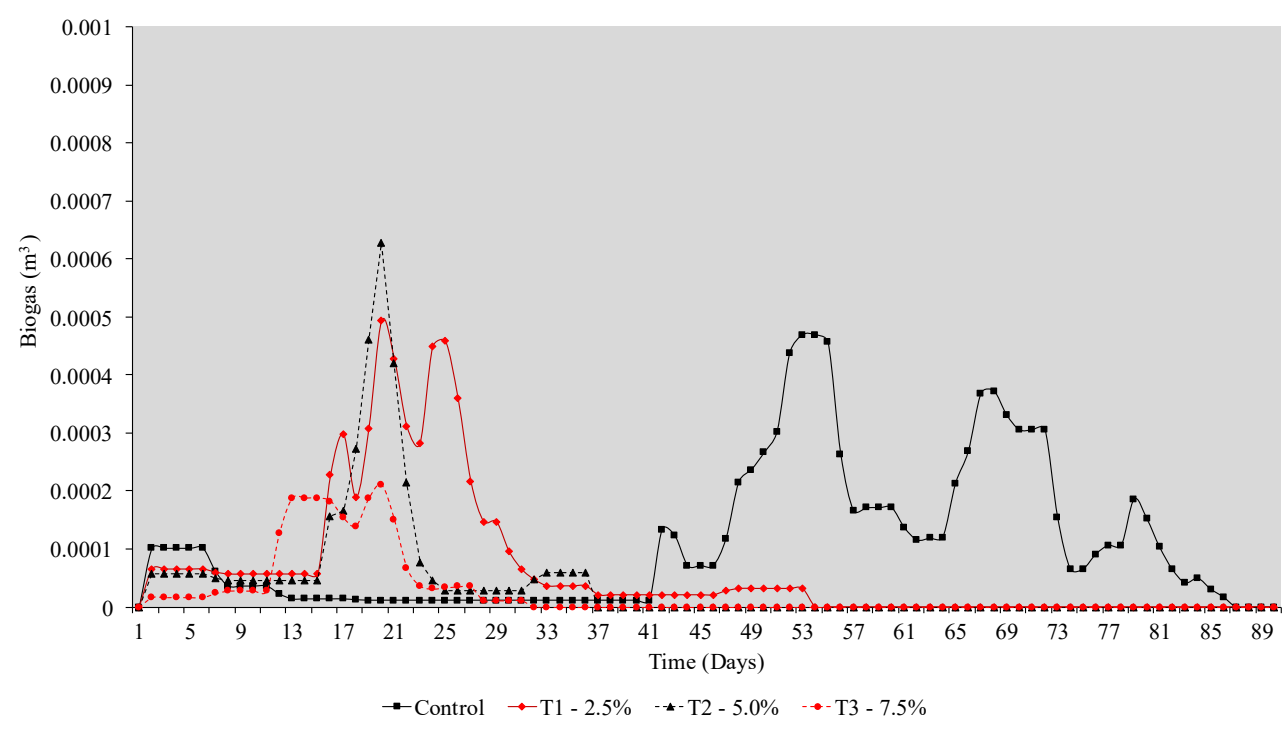

FIGURE 2. Daily biogas production from batch anaerobic reactorsfed laying hen manure different levels of biochar.

It is known that in the beginning of the fermentative process for biogas production there is higher activity of acidogenic and acetogenic microorganisms which convert complex molecules into precursors for biogas production (Siddique \& Wahid, 2018). This class of microorganism is known for better development and activity under a more acidified $\mathrm{pH}$, and, since $\mathrm{pH}$ substrates were not corrected to neutral condition or below, certain instability may have happened and lower fermentative action of this microorganisms' group took place at that time, which certainly could have influenced the kinetics of overall substrate's metabolization, lowering the conversion rate of precursors into biogas.

Inclusions of biochar initiated rapid biogas production as illustrated in figure 2, starting slowly during the first week, peaking around the $20^{\text {th }}$ to $25^{\text {th }}$ day, and ceasing production around the $36^{\text {th }}$ day. This early biogas production might be due to an increase in the hydrolysis rate 
in the presence of biochar as suggested by Ma et al. (2019). Yang \& Wang (2019) mentioned that activation of important hydrolases such as proteases, cellulases and amylase can be attributed to the presence of biochar. Probably higher activity of proteases rapidly promotes generation of ammonia nitrogen which is efficiently used as substrate by microorganisms' growth and development. On the other hand, the control treatment displayed an initial first peak of biogas production in the first week, but only started to produce significant amounts of biogas after the $41^{\text {st }}$ day, with a peak biogas production around the $53^{\text {rd }}$ day and another in the $66^{\text {th }}$ day, before subsiding.

For better understanding the differences in biogas production over time, figure 3 displays the development and cumulative biogas production of batch anaerobic reactors feed laying hen manure different levels of biochar.

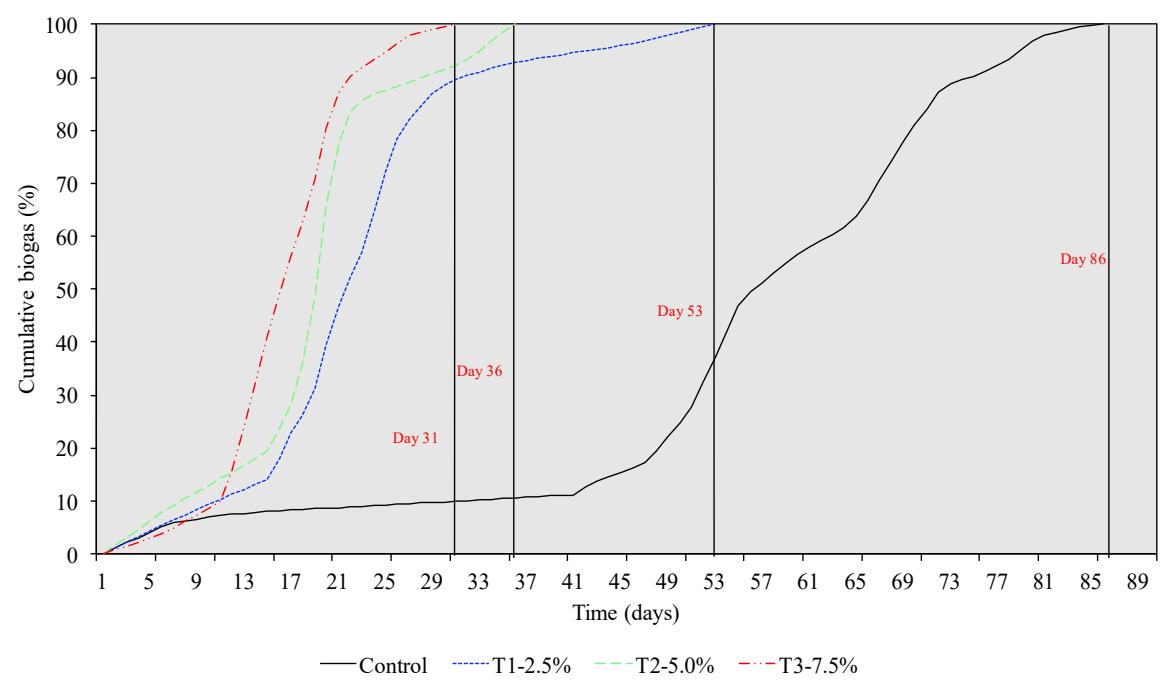

FIGURE 3. Cumulative biogas production from batch anaerobic reactors fed laying hen manure at different levels of biochar.

In spite of adversities, reactors fed hen manure with different inclusions of biochar displayed fast start-up of biogas production (Figures 3) which can also be attributed to a better $\mathrm{C}: \mathrm{N}$ ratio at the beginning of the process which met the minimum metabolic requirements of fermentative microorganisms contributing to an early metabolization of organic matter and generation of volatile fatty acids for biogas production.

$\mathrm{C}: \mathrm{N}$ ratio has a great influence on overall biogas production since it directly influences how organic matter is used by microorganisms. Despite lower biogas production than the control, a $2.5 \%$ inclusion rate of biochar may be an option in systems to achieve early biogas production. However, besides an early start-up of biogas production, biogas plants look for a longer production at a sustained high level, and taking this into account further research may be done using inoculum, since it not only improves biogas production but also would provide better conditions regarding monitoring parameters for microorganism development and therefore fermentative processes can be carried under conditions that favors biogas production at its high level.

Table 5 summarizes mean values of total nitrogen, phosphorous and calcium concentration of substrate and digestate from batch anaerobic reactors fed laying hen manure with different inclusions of biochar. The highest substrate TN concentration was observed in the control, which was probably due to the higher inclusion of manure on that treatment. No statistical difference was detected for digestate material, with values in the range of 4.57 to $4.93 \%$ on DM basis.

TABLE 5. Mean values for Total nitrogen (TN), phosphorous (TP), and calcium concentration of digestate material from anaerobic reactors fed laying hen manure diluted in water with different inclusions of biochar (values expressed in $\mathrm{g} / 100 \mathrm{~g}$ ).

\begin{tabular}{lllllll}
\hline \multirow{2}{*}{ Treatments } & \multicolumn{2}{l}{ Total nitrogen } & \multicolumn{2}{l}{ Total phosphorous } & \multicolumn{2}{l}{ Calcium } \\
\cline { 2 - 7 } & Substrate & Digestate & Substrate & Digestate & Substrate & Digestate \\
\hline Control & $3.01 \mathrm{a}$ & $4.60 \mathrm{a}$ & $4.71 \mathrm{~b}$ & $7.11 \mathrm{a}$ & $1.19 \mathrm{a}$ & $1.72 \mathrm{a}$ \\
Biochar $2.5 \%$ & $2.24 \mathrm{~b}$ & $4.76 \mathrm{a}$ & $5.82 \mathrm{a}$ & $7.22 \mathrm{a}$ & $1.39 \mathrm{a}$ & $1.50 \mathrm{a}$ \\
Biochar 5.0\% & $2.38 \mathrm{~b}$ & $4.57 \mathrm{a}$ & $4.48 \mathrm{~b}$ & $6.98 \mathrm{a}$ & $1.30 \mathrm{a}$ & $1.35 \mathrm{a}$ \\
Biochar 7.5\% & $2.31 \mathrm{~b}$ & $4.93 \mathrm{a}$ & $4.87 \mathrm{~b}$ & $5.77 \mathrm{~b}$ & $1.47 \mathrm{a}$ & $1.52 \mathrm{a}$ \\
\hline P value & 0.001 & 0.613 & 0.006 & 0.011 & 0.579 & 0.246 \\
CV $(\%)$ & 5.65 & 7.69 & 6.52 & 6.41 & 18.60 & 13.25 \\
\hline
\end{tabular}

Means followed by different letters in the same row differ at $5 \%$ through Tukey test.

It should be noted that the use of non-stable digestate or even fresh raw manure in crop fields can lead to a caustic effect on plants due to rapid availability of nitrogen, and thus previous treatment are generally needed to attain a stable material. Use of non-stable digestate can inhibit seeds germination and root growth, as well as offering sanitary risks in vegetables cultivation and soil due to pathogenic microorganisms (Sediyama et al., 2008).

Higher concentration of substrate Total-P was detected for the $2.5 \%$ treatment while no difference was 
revealed among the other treatments, with values ranging from 4.48 to $4.87 \%$ on DM basis. A lower Total-P concentration was seen in the $7.5 \%$ treatment (Table 5 ).

There was no difference among treatments for calcium concentrations in substrate and digestate, with values ranging from 1.19 to $1.47 \%$ and 1.35 to $1.72 \%$, respectively. High values of $\mathrm{Ca}$ substrate concentration might have been due to higher calcium inclusion in the hens' diet which is indeed important for bone calcification, eggshell formation and other equally important metabolic functions. As previously mentioned, the manure used was a mixture of feces, feathers, waste feed, eggshell and egg contents, and others; All these components can increase the quantity of different macro and micro-nutrients on manure, including calcium.

Increased digestate concentrations of nitrogen, phosphorous and calcium were detected compared with substrate occurred as a function of the cumulative effects caused by break down of organic matter by fermentative microorganisms. Since the AD process using laying hen manure diluted in water with addition of biochar did not display a persistent improvement in biogas production over the 86 day experiment, lower fermentative activity of organic matter probably influenced a lower accumulated content of nitrogen, phosphorous and calcium on final digestate material.

\section{CONCLUSIONS}

Based on the results of this study, inclusions of biochar in the anaerobic digestion of laying hen manure diluted in water to $7 \%$ total solids in a batch reactor for 86 days resulted in lower concentrations of total ammonia nitrogen, which were in an acceptable range for anaerobic digestion process, however, despite this, biochar did not contribute to the increase of overall biogas yield per kilogram of feedstock, substrate, total solids, or volatile in and volatile solids removed. In terms of digestate quality, no significant contribution was found, despite the increase of total nitrogen, phosphorous and calcium in final the digestate

\section{ACNOWLEDGEMENTS}

The authors thank the National Council for Scientific and Technological Development (CNPq) for the granting of a scholarship and financial aid. This study was also financed in part by the Coordenação de Aperfeiçoamento de Pessoal de Nível Superior - Brasil (CAPES) - Finance Code 001.

\section{REFERENCES}

Andrade WR, Xavier CAN, Coca FOCG, Arruda LDO, Santos TMB (2016) Biogas production from ruminant and monogastric animal manure codigested with manipueira. Archivos de Zootecnia 65(251):375-380.

APHA, AWWA, WPCF (2017) Standard methods for the examination of water and wastewater. Washington, $23^{\text {rd }} \mathrm{ed}$.

Carvalho AMX, Mendes FQ (2017) SPEED Stat: a minimalist and intuitive spreadsheet program for classical experimental statistics. Lavras, UFLA, 333p.
Cuetos MJ, Martinez EJ, Moreno R, Gonzalez R, Otero M, Gomez X (2017) Enhancing anaerobic digestion of poultry blood using activated carbon. Journal of advanced research 8(3):297-307. DOI: https://doi.org/10.1016/j.jare.2016.12.004

Dalkılıc K, Ugurlu A (2015) Biogas production from chicken manure at different organic loading rates in a mesophilic-thermopilic two stage anaerobic system. Journal of Bioscience and Bioengineering 120(3):315-322. DOI: https://doi.org/10.1016/j.jbiosc.2015.01.021

Fantozzi F, Buratti C (2009) Biogas production from different substrates in an experimental continuously stirred tank reactor anaerobic digester. Bioresource Technology 100(23):5783-5789. DOI: https://doi.org/10.1016/j.biortech.2009.06.013

Farias RM, Orrico Junior AP, Orrico ACA, Garcia RG, Centurion SR, Fernandes ARM (2012) Biodigestão anaeróbia de dejetos de poedeiras coletados após diferentes períodos de acúmulo. Ciência Rural 42(6):10891094. DOI: http://dx.doi.org/10.1590/S010384782012005000031

Farrow C, Crolla A, Kinsley C, Mcbean E (2016) Anaerobic digestion of chicken manure: Process optimization employing struvite precipitation and novel digestion technologies. Environmental Progress \& Sustainable Energy 36(1):73-82. DOI: https://doi.org/10.1002/ep.12442

Guo M, Uchimiya SM, He Z (2016) Agricultural and environmental applications of biochar: Advances and barriers. Soil Science Society of America, 504p. DOI: https://doi.org/10.2136/sssaspecpub63.2014.0054

Ho L, Ho G (2012) Mitigating ammonia inhibition of thermophilic anaerobic treatment of digested piggery wastewater: use of $\mathrm{pH}$ reduction, zeolite, biomass and humic acid. Water Resource (46):4339-4350. DOI: https://doi.org/10.1016/j.watres.2012.05.016

Jiménez EI, Garcia VP (1992) Relationships between organic carbon and total organic matter in municipal solid wastes and city refuse composts. Bioresource Technology (41):265-272. DOI: https://doi.org/10.1016/09608524(92)90012-M

Luo C, Lü F, Shao L, He P (2015) Application of ecocompatible biochar in anaerobic digestion to relieve acid stress and promote the selective colonization of functional microbes. Water research (68)710-718. DOI: https://doi.org/10.1016/j.watres.2014.10.052

Ma J, Pan J, Qiu L, Wang Q, Zhang Z (2019) Biochar triggering multipath methanogenesis and subdued propionic acid accumulation during semi-continuous anaerobic digestion. Bioresource Technology (293):122026. DOI: https://doi.org/10.1016/j.biortech.2019.122026

Molaey R, Bayrakdar A, Sürmeli RÖ, Çalli B (2018) Anaerobic digestion of chicken manure: Mitigating process inhibition at high ammonia concentrations by selenium supplementation. Biomass and Bioenergy (108):439-446. DOI:

https://doi.org/10.1016/j.biombioe.2017.10.050 
Mumme J, Srocke F, Heeg K, Werner M (2014) Use of biochars in anaerobic digestion. Bioresource Technology (164):189-197. DOI:

https://doi.org/10.1016/j.biortech.2014.05.008

Niu Q, Hojo T, Qiao W, Qiang H, Li YY (2014)

Characterization of methanogenesis, acidogenesis and hydrolysis in thermophilic methane fermentation of chicken manure. Chemical Engineering Journal (244):587596. DOI: https://doi.org/10.1016/j.cej.2013.11.074

Pan J, Ma J, Zha L, Lio T, Mei Z, Liu H (2019) Achivement of biochar application for enhanced Anaerobic digestion:

Review. Bioresource Technology 292:122058. DOI: https://doi.org/10.1016/j.biortech.2019.122058

Rahman MA, Møller HB, Saha CK, Alam MM, Wahid R, Feng L (2018) Anaerobic co-digestion of poultry droppings and briquetted wheat straw at mesophilic and thermophilic conditions: Influence of alkali pretreatment. Renewable energy (128):241-249. DOI: https://doi.org/10.1016/j.renene.2018.05.076

Sediyama MA, Vidigal SM, Pedrosa MW, Pinto CL, Salgado LT (2008) Fermentação de esterco de suínos para uso como adubo orgânico. Revista Brasileira de Engenharia Agrícola e Ambiental 12(6):638-645.DOI: http://dx.doi.org/10.1590/S1415-43662008000600011

Siddique MNI, Wahid ZA (2018) Achievements and perspectives of anaerobic co-digestion: A review. Journal of cleaner production (194):359-371. DOI:

https://doi.org/10.1016/j.jclepro.2018.05.155

Vicente Jr DJ, Costa MSDM, Costa LA, Pereira DC, Santos FTD (2018) Anaerobic digestion and co-digestion of poultry litter submitted to different reuses. Engenharia Agrícola 38(6):961-967. DOI: http://dx.doi.org/10.1590/1809-4430
Wang X, Lu X, Li F, Yang G (2014) Effects of temperature and carbon-nitrogen $(\mathrm{C} / \mathrm{N})$ ratio on the performance of anaerobic co-digestion of dairy manure, chicken manure and rice straw: focusing on ammonia inhibition. PloS one 9(5):e97265. DOI: https://doi.org/10.1371/journal.pone.0097265

Wang F, Pei M, Qiu L, Yao Y, Zhang C, Qiang H (2019) Performance of anaerobic digestion of chicken manure under gradually elevated organic loading rates. International journal of environmental research and public health 16(12):2239.DOI:

https://doi.org/10.3390/ijerph16122239

Yang G, Wang J (2019) Synergistic enhancement of biohydrogen production from grass fermentation using biochar combined with zero-valent iron nanoparticles. Fuel (251):420-427. DOI:

https://doi.org/10.1016/j.fuel.2019.04.059

Yenigün O, Demirel B (2013) Ammonia inhibition in anaerobic digestion: a review. Process Biochemestry (48):901-911. DOI: https://doi.org/10.1016/j.procbio.2013.04.012

Yun YM, Kim DH, Cho SK, Shin HS, Jung KW, Kim HW (2016) Mitigation of ammonia inhibition by internal dilution in high-rate anaerobic digestion of food waste leachate and evidences of microbial community response. Biotechnology and bioengineering 113(9):18921901. DOI: https://doi.org/10.1002/bit.25968

Zanato JAF (2014) Produção e qualidade do biogás gerado com os dejetos de diferentes espécies animais. Tese, Jaboticabal, Universidade Estadual Paulista, Faculdade de Ciências Agrárias e Veterinárias.

Zhang T, Yang Y, Liu L, Han Y, Ren G, Yang G (2014) Improved biogas production from chicken manure anaerobic digestion using cereal residues as cosubstrates. Energy \& Fuels 28(4):2490-2495. DOI: https://doi.org/10.1021/ef500262m 


\section{ERRATUM}

In the paper "RESPONSE FROM ANAEROBIC DIGESTION OF LAYING HEN MANURE WITH BIOCHAR ADDITION", with DOI number: 10.1590/1809-4430-Eng.Agric.v40n3p315-321/2020, published in the journal Agricultural Engineering 40 (3):315-321, on the page 320:

Where it reads:

\section{ACNOWLEDGEMENTS}

The authors thank the National Council for Scientific and Technological Development (CNPq) for the granting of a scholarship and financial aid.

It should read:

\section{ACNOWLEDGEMENTS}

The authors thank the National Council for Scientific and Technological Development (CNPq) for the granting of a scholarship and financial aid. This study was also financed in part by the Coordenação de Aperfeiçoamento de Pessoal de Nível Superior - Brasil (CAPES) - Finance Code 001. 